\title{
Evaluating the Potential of Protected Cultivation for Off-Season Leafy Vegetable Production: Prospects for Crop Productivity and Nutritional Improvement
}

\author{
Srinivasan Ramasamy ${ }^{1 *}$, Mei-Ying Lin ${ }^{1}$, Wan-Jen Wu ${ }^{2}$, Hsin-I Wang ${ }^{2}$ and \\ Paola Sotelo-Cardona ${ }^{1}$ \\ ${ }^{1}$ Safe and Sustainable Value Chains Flagship Program, World Vegetable Center, Tainan, Taiwan, ${ }^{2}$ Healthy Diets Flagship \\ Program, World Vegetable Center, Tainan, Taiwan
}

OPEN ACCESS

Edited by:

Stefania Grando,

Consultant, Ascoli Piceno, Italy

Reviewed by:

Chayon Goswami,

Bangladesh Agricultural

University, Bangladesh

Alexandru Rusu,

Biozoon Food Innovations $\mathrm{GmbH}$,

Germany

*Correspondence:

Srinivasan Ramasamy srini.ramasamy@worldveg.org

Specialty section:

This article was submitted to Nutrition and Sustainable Diets,

a section of the journal

Frontiers in Sustainable Food Systems

Received: 26 June 2021 Accepted: 01 November 2021 Published: 26 November 2021

Citation:

Ramasamy S, Lin M-Y, Wu W-J, Wang $\mathrm{H}-\mathrm{I}$ and Sotelo-Cardona $P$ (2021) Evaluating the Potential of Protected Cultivation for Off-Season

Leafy Vegetable Production: Prospects for Crop Productivity and Nutritional Improvement. Front. Sustain. Food Syst. 5:731181 doi: 10.3389/fsufs.2021.731181
The effects of different protective structures on horticultural and nutritional yield of amaranth and water spinach were studied in three seasons of 2020-2021 in Taiwan. The number of people that can receive recommended dietary intake of iron and $\beta$-Carotene from vegetables grown under different production conditions was also estimated. The yield of white and red amaranths was consistently better (7.68-19.70 t/ha) under pink poly-net house in all the seasons, but the yield of water spinach was consistently better under white poly-net house (16.25-20.88 t/ha). Spider mite (fall \& spring) and aphid (winter) infestation was mostly observed on all crops under poly-net houses. Neoxanthin, lutein and $\beta$-carotene were almost two-fold higher in red amaranth harvested from poly-net houses than open field. Based on the RDI values, $\beta$-Carotene supply to both men and women $(14+)$ was consistently higher in all crops produced under pink ploy-net houses in all seasons, except for white amaranth produced under white poly-net house during winter. Its supply to 64,788 more men and 83,298 more women was estimated for red amaranth harvested from pink poly-net house than other production conditions. $\alpha$-carotene was 2-3 fold higher in amaranths and water spinach harvested from poly-net houses than open field. The iron content of the amaranths was lower in poly-net houses (234.50-574.04 $\mathrm{g} / \mathrm{ha}$ ) than open field $(645.42-881.67 \mathrm{~g} / \mathrm{ha})$ in the fall, but its supply from pink poly-net house was comparable with open field in the winter. However, pink poly-net house was the highest iron supplier from water spinach $(323.90 \mathrm{~g} / \mathrm{ha})$ in the winter, which was estimated to provide iron to 19,450-22,939 more men and women than other production conditions. Both poly-net houses were the sole supplier of iron through amaranths in the spring, with pink poly-net house supplying iron to 2,000-5,000 more men and women. Thus, protected cultivation not only leads to more marketable yields but also results in higher quantities of health promoting nutrients. Hence, pink poly-net house may be considered to produce more nutritious vegetables, especially during the off-season to bridge the gaps in the seasonal variations in vegetable consumption, besides providing better income opportunities to the smallholder farmers.

Keywords: colored net structures, off-season production, nutritious vegetables, iron, carotenoids, amaranth, water spinach 


\section{INTRODUCTION}

Leafy vegetables are an important component in the farming systems as well as in the diets of people in Asia and Africa. Various leafy vegetables such as leafy brassicas (Chinese cabbage, pak-choi, kale, mustard, etc.), amaranth, water spinach, Malabar spinach, jute mallow, chayote, spider plant and African nightshade are grown in different parts of Asia and Africa, and they are mostly considered as "traditional" vegetables, since they are a part of alimentary traditions and cultural identity (Towns and Shackleton, 2018). These vegetables play an important role among the smallholder farmers, since they are a source of food and nutritional security, besides serving as income generating high value crops. For instance, Cambodian farmers were able to generate a revenue of US\$ 4,776/ha from Chinese kale cultivation, whereas Vietnamese farmers earned US\$ 5,070/ha from water spinach cultivation (Genova et al., 2010). Vegetable production has led to 3-14 times higher profits per hectare than in rice farming in Cambodia and Vietnam, while profits per labor-day are double (Joosten et al., 2015). The leafy vegetables are repeat-cycle crops, and the average length of growing period is 7-8 weeks, though farmers often re-sow their field after harvest or use staggered sowing to extend the harvest period (Schreinemachers et al., 2017). Thus, leafy vegetables are an important source of income for smallholder farmers.

Leafy vegetables are also an important source of nutrients. The leafy vegetables including amaranth and Chinese kale supply vitamins (especially vitamins A, C, folate), minerals such as calcium, potassium, iron, phosphorus, zinc, copper and manganese and dietary fiber to the human diet (Makobo et al., 2010; Ebert et al., 2011; Fowler, 2011). Water spinach is rich in protein, calcium, pro-vitamin A and vitamin C (Westphal, 1994). In addition, water spinach is a key contributor of lutein/zeaxanthin (Pan et al., 2018). However, the production of leafy vegetables is highly seasonal. For instance, amaranth is the predominant leafy vegetable in the summer months in Taiwan. Although water spinach is also grown during the summer months, leafy brassicas are mostly produced during the cooler months (Wang and Ebert, 2012).

Production of leafy vegetables is constrained by abiotic and biotic factors. Typhoons, for example, which regularly hit Taiwan during summer months, are often associated with heavy rainfall of up to $3,000 \mathrm{~mm}$ and subsequent flooding. Such extreme weather conditions not only lead to heavy yield losses in leafy vegetables, but also escalates their prices in the market (Wang and Ebert, 2012). Prices may soar to 3-5 times the normal level (Lee and Yang, 1999), which reduce their consumption during the summer months. Biotic factors such as pests and diseases also adversely affect the productivity of leafy vegetables. The leaf webber, Spoladea recurvalis F. (Lepidoptera: Crambidae) causes significant yield losses on amaranth in Asia (Hsu and Srinivasan, 2012) and Africa (Smith et al., 2018). White rust of amaranth, caused by Albugo bliti (Biv.) Kuntze, is a serious problem during the hot and humid conditions in Taiwan as well as in Southeast Asia (Grubben and Van Sloten, 1981; National Research Council, 1984), which causes almost $100 \%$ infection, considerably reducing the commercial value of the crop.
Spotted tortoise beetle, Aspidomorpha miliaris F. (Coleoptera: Chrysomelidae), Convolvulus hawk-moth, Agrius convolvuli L. (Lepidoptera: Sphingidae), sweet potato stem borer, Omphisa anastomosalis Guenée (Lepidoptera: Crambidae) and common armyworm, Spodoptera litura F. (Lepidoptera: Noctuidae) are the major pests of water spinach (Muniappan et al., 2012).

Most leafy vegetables can be successfully grown under protective structures year-round. The leafy vegetables grown under protective structures using plug seedlings have been demonstrated to be grown faster, and harvested earlier with fewer pest problems compared to conventional production using direct seeding (Lee and Yang, 1999). Production under protective structures not only increases the total annual crop yield per unit area, but also improves the quality, besides extending their production period (Nordey et al., 2017). In recent years, use of color shade nets was found to protect the crops from adverse environmental conditions, improve the quality of vegetables and maintain post-harvest quality for an extended period (Ilić et al., 2018). But there is no evidence yet on how these shades affect yield or nutritional content of leafy greens. Hence, the objective of the current study is to determine the effects of different protective structures on the horticultural and nutritional yield of amaranth and water spinach across the seasons in Taiwan.

\section{MATERIALS AND METHODS}

\section{Field Trials}

\section{Location and Seasons}

The study was conducted at the World Vegetable Center, Shanhua, Tainan, Taiwan $\left(23^{\circ} 08^{\prime} 29^{\prime \prime} \mathrm{N}, 120^{\circ} 19^{\prime} 15^{\prime \prime} \mathrm{E}\right)$ at a mean elevation of $9 \mathrm{~m}$ above the sea level. The trials were conducted following a complete randomized block design (CRBD), with three blocks. Three field trials were conducted during fall season (Sept 23-Oct 28, 2020), winter season (Dec 09 2020-Feb 8 2021), and spring season (March 24-May 5, 2021).

\section{Treatments and Data Collection}

Three leafy vegetables, viz., amaranth (Amaranthus tricolor, $\mathrm{cv}$. white amaranth and cv. red amaranth) and water spinach (Ipomoea aquatica cv. kangkong) were compared under white poly-net house (clear color pattern, allowing full sunlight spectrum), pink poly-net house (magenta color pattern, Blue: Green: Red: Far Red percentages B:G:R:FR = 40:32:60:127, and $80 \%$ density knitted shade net) and open field conditions. Nets were manufactured by SpectralX, LeBio International Technology Corp. Ltd, Tainan, Taiwan. Each poly-net house was 7 × 12 × 4-m (W:L:H). Hence, each production system was considered as a treatment, and four replications were maintained for each treatment. The seeds were obtained from Hsinyusen seed company (Yunlin County, Taiwan). The crops were sown on raised bed (9.2-m long and 1-m wide) in each replication and managed following the customary production practices, including surface irrigation at weekly intervals and manual weeding three times in the season. About $25 \mathrm{~kg}$ of organic fertilizer (compost) (Chung Rong Industrial Company, Tainan, Taiwan) was applied to each bed. The incidence of pests and diseases were recorded from each replication. Spider mite 
occurred in the fall and spring seasons, whereas aphid occurred in the winter. The spider mite damage was rated using a $0-5$ scale (Nihoul et al., 1991) and aphid damage was rated using a $1-5$ scale: 1 (<10 aphids), 2 (11-50 aphids), 3 (51-100 aphids), 4 (101-500 aphids) and 5 (>500 aphids). At harvest, the vegetables were sorted and graded as marketable and unmarketable, and the yield of each category was recorded. The climatic conditions (temperature and relative humidity) in each replication were recorded throughout the season. Besides horticultural yield, nutritional analysis including dry matter, anti-oxidant activity, iron, and carotenoids (violaxanthin, neoxanthin, lutein, $\alpha-$ Carotene and $\beta$-Carotene) was carried out in all the crops and treatments. At harvest, pooled plant samples were collected from each treatment and used for the nutritional analysis. Two biological replications were used for each crop, and the mean value for each nutritional compound was used to estimate the total nutritional yield from the unit area (one hectare).

\section{Nutritional Analysis \\ Iron}

AOAC method no. 975.03 was used for iron determination (AOAC, 1990). Briefly, $0.2 \mathrm{~g}$ of dried sample powder from each treatment was mixed with $5 \mathrm{ml}$ of $36 \mathrm{~N}$ sulfuric acid in the digestion flask. The samples were then kept aside overnight. The elemental analysis was continued by heating the digestion tubes at $300^{\circ} \mathrm{C}$ for $2 \mathrm{~h}$. The contents were then cooled to about $150^{\circ} \mathrm{C}$, and $2-3 \mathrm{ml}$ of $30 \%$ hydrogen peroxide ( $\mathrm{H} 2 \mathrm{O} 2)$ was added. The tubes were placed in the digester at $300^{\circ} \mathrm{C}$ for $1 \mathrm{~h}$ to make the mixture transparent. The mixture was then cooled to about $40^{\circ} \mathrm{C}$, and diluted with $50 \mathrm{ml}$ distilled water. The iron content was determined in each sample using inductively coupled plasmaoptical emission spectrometry (ICP-OES) instrument (8000 ICPOES, PerkinElmer, Waltham, MA, USA). The standards were also prepared to make the calibration curve.

\section{Antioxidant Activity}

Leafy vegetable samples were analyzed for antioxidant activity (AOA) by ARP method (Arnao et al., 2001). This method measures the capacity of different components to scavenge the ABTS radical cation as compared to the standard antioxidant Trolox $(0-4 \mathrm{mM})$ in a dose response curve. $0.1 \mathrm{~g}$ of freeze-dried powder with $9.9 \mathrm{ml}$ of methanol was added in a centrifuge tube. The mixture was shaken for $4 \mathrm{~h}$ at high speed, and centrifuged at $6,000 \mathrm{rpm}$ for $10 \mathrm{~min}$. The supernatant was transferred into vials and stored at $-70^{\circ} \mathrm{C}$ until analyzed. The reaction mixture contained $10 \mathrm{ml}$ of $20 \mathrm{mM}$ ABTS / $50 \mathrm{mM}$ sodium phosphate buffer ( $\mathrm{pH} 7.5$ ) with $0.5 \mathrm{ml}$ of HRP stock solution and $90 \mathrm{ml}$ of ethanol. The mixture was then centrifuged at $12,000 \mathrm{rpm}$ for $5 \mathrm{~min}$ and the supernatant was collected. Twenty microliters of antioxidant sample with appropriate dilution in water or methanol was added to the $2 \mathrm{~mL}$ of the reaction medium. The decrease in absorbance, which was proportional to the ABTS quenched, was determined after $5 \mathrm{~min}$ by spectrophotometer (U2001, HITACHI, Tokyo, Japan) at $730 \mathrm{~nm}$. The AOA of a sample for the ARP assay was measured within the linear relationship of concentration vs. optical density decrease, and presented as Trolox equivalent (TE) in $\mu \mathrm{mol} / \mathrm{g}$ vegetable sample (fresh weight basis).

\section{Dry Matter}

Dry matter was determined from the weight difference of $1.0 \mathrm{~g}$ of fine powder before and after placing in an oven (DN 63, Yamato, Tokyo, Japan) at $135^{\circ} \mathrm{C}$ for $2 \mathrm{~h}$.

\section{Carotenoids}

The carotene content was determined using the highperformance liquid chromatography (HPLC) method (Rodriguez-Amaya and Kimura, 2004). Briefly, $0.1 \mathrm{~g}$ of freezedried powder was mixed thoroughly with $0.5 \mathrm{ml}$ of distilled water and $4.5 \mathrm{ml}$ of acetone in glass vial, and the mixture was shaken for $30 \mathrm{~min}$. Two milliliters of supernatant were pipetted into $10 \mathrm{ml}$ test tube, and then dried using $\mathrm{N}_{2}$ gas at $36^{\circ} \mathrm{C}$ for $20 \mathrm{~min}$. To the dried sample, $100 \mu \mathrm{l}$ of tetrahydrofuran (THF) and 1,900 $\mu \mathrm{l}$ Methanol was added and mixed well. The solution was then filtered through a $0.22 \mu \mathrm{m}$ membrane and the final solution of $2 \mathrm{ml}$ was injected into HPLC vials by using glass syringes enclosed with $0.22 \mu \mathrm{m}$ pore size, and $13 \mathrm{~mm}$ diameter syringe filter. Separation and identification of carotenoids was performed using a HPLC system (Waters 2695, Milford, MA, USA) equipped with an auto-sampler, a photodiode array detector (Waters 996) monitoring at wavelength between 210 and $700 \mathrm{~nm}$. The static phase was a C 30 Column $\left(\mathrm{YMC}^{\mathrm{TM}}\right.$ Carotenoid $3.0 \mu \mathrm{m}, 4.6 \times 150 \mathrm{~mm}$ ). The running conditions were set at $30^{\circ} \mathrm{C}$ using a gradient at $1.3 \mathrm{~mL} / \mathrm{min}$ from 0 to $1 \%$ THF in methanol at $0-15 \mathrm{~min}, 1-25 \%$ THF in methanol at $15-25 \mathrm{~min}$, $25-70 \%$ THF in methanol at $25-50 \mathrm{~min}$, and the final $100 \%$ $\mathrm{THF}$ at $50-60 \mathrm{~min}$. Identification of sample carotenoids was performed by comparing retention time and light absorption spectra (350-700 nm) of known standards. The peak areas were calibrated against known amounts of standards.

\section{Estimating the Number of People That Can Receive Recommended Dietary ilntake of Iron and $\beta$-Carotene From Amaranth and Water Spinach Grown Under Different Production Conditions}

Based on the nutritional yield per hectare, the number of people that can receive recommended dietary intake (RDI) of iron and $\beta$ Carotene from white amaranth, red amaranth and water spinach were estimated. We have attempted to pursue this perspective in the current study, since most of the existing studies attempt to understand the impact of agronomic practices on the yield but not on the nutrients. We chose only iron and $\beta$-carotene, although $\alpha$-carotene was also a pro-vitamin A carotenoid. The revised bio-efficacy of $\alpha$-carotene in a mixed diet is 1: 24 (Institute of Medicine, 2001), and hence it has been estimated to be $16.8-$ $21.6 \mathrm{mg} /$ day $\alpha$-carotene that would fulfill the RDI for vitamin A of healthy adults. Since the $\alpha$-carotene content in the amaranth and water spinach was comparatively lower than $\beta$-carotene, we did not include it in the estimation. Violaxanthin, neoxanthin and lutein are the epoxy carotenoids, which might be degraded by to the acidic conditions in the stomach (Asai et al., 2008; Britton et al., 2009; Maoka and Etoh, 2010), and hence we also did not include them in the estimation. The widely accepted 
TABLE 1 | Analyses for marketable yield and nutritional content of white amaranth under colored poly-net house, white poly-net house, and open field conditions in Taiwan during $2020--2021$.

\begin{tabular}{|c|c|c|c|c|c|c|c|c|c|c|c|c|c|c|c|c|c|c|c|}
\hline \multirow[t]{2}{*}{ Source } & \multirow[t]{2}{*}{ df } & \multicolumn{2}{|c|}{ Yield } & \multicolumn{2}{|c|}{ Dry matter } & \multicolumn{2}{|c|}{$\mathrm{Fe}$} & \multicolumn{2}{|c|}{ Violaxanthin } & \multicolumn{2}{|c|}{ Neoxanthin } & \multicolumn{2}{|c|}{ Lutein } & \multicolumn{2}{|c|}{$\alpha$-Carotene } & \multicolumn{2}{|c|}{ B-Carotene } & \multicolumn{2}{|c|}{$A O A$} \\
\hline & & $\mathbf{F}$ & $\operatorname{Pr}>F$ & $\mathbf{F}$ & $\operatorname{Pr}>F$ & $\mathbf{F}$ & $\operatorname{Pr}>\mathrm{F}$ & $\mathbf{F}$ & $\operatorname{Pr}>F$ & $\mathbf{F}$ & $\operatorname{Pr}>\mathrm{F}$ & $\mathbf{F}$ & $\operatorname{Pr}>F$ & $\mathbf{F}$ & $\operatorname{Pr}>F$ & $\mathbf{F}$ & $\operatorname{Pr}>F$ & $\mathbf{F}$ & $\operatorname{Pr}>\mathbf{F}$ \\
\hline Model & 17 & 30.32 & $<0.0001$ & 30.55 & $<0.0001$ & 114.53 & $<0.0001$ & 45.92 & $<0.0001$ & 29.23 & $<0.0001$ & 28.98 & $<0.0001$ & 32.92 & $<0.0001$ & 28.03 & $<0.0001$ & 29.38 & $<0.0001$ \\
\hline Season & 2 & 88.46 & $<0.0001$ & 90.84 & $<0.0001$ & 225.10 & $<0.0001$ & 134.51 & $<0.0001$ & 76.20 & $<0.0001$ & 75.72 & $<0.0001$ & 45.23 & $<0.0001$ & 70.23 & $<0.0001$ & 81.03 & $<0.0001$ \\
\hline Treatment & 2 & 43.99 & $<0.0001$ & 40.42 & $<0.0001$ & 83.80 & $<0.0001$ & 2.57 & 0.1100 & 67.31 & $<0.0001$ & 67.49 & $<0.0001$ & 155.55 & $<0.0001$ & 78.09 & $<0.0001$ & 56.92 & $<0.0001$ \\
\hline Season $*$ Treatment & 4 & 16.61 & $<0.0001$ & 18.02 & $<0.0001$ & 193.11 & $<0.0001$ & 57.93 & $<0.0001$ & 9.72 & 0.0004 & 9.35 & 0.0005 & 2.92 & 0.0571 & 6.40 & 0.0033 & 12.13 & 0.0001 \\
\hline
\end{tabular}

The bold values indicate the statistical significance for Season ${ }^{*}$ Treatment.

TABLE 2 | Analyses for marketable yield and nutritional content of red amaranth under colored poly-net house, white poly-net house, and open field conditions in Taiwan during $2020-2021$.

\begin{tabular}{|c|c|c|c|c|c|c|c|c|c|c|c|c|c|c|c|c|c|c|c|}
\hline \multirow[t]{2}{*}{ Source } & \multirow[t]{2}{*}{ df } & \multicolumn{2}{|c|}{ Yield } & \multicolumn{2}{|c|}{ Dry matter } & \multicolumn{2}{|c|}{$\mathrm{Fe}$} & \multicolumn{2}{|c|}{ Violaxanthin } & \multicolumn{2}{|c|}{ Neoxanthin } & \multicolumn{2}{|c|}{ Lutein } & \multicolumn{2}{|c|}{$\alpha$-Carotene } & \multicolumn{2}{|c|}{ B-Carotene } & \multicolumn{2}{|c|}{ AOA } \\
\hline & & $\mathbf{F}$ & $\operatorname{Pr}>\mathrm{F}$ & $\mathbf{F}$ & $\operatorname{Pr}>\mathrm{F}$ & $\mathbf{F}$ & $\operatorname{Pr}>\mathrm{F}$ & $\mathbf{F}$ & $\operatorname{Pr}>\mathrm{F}$ & $\mathbf{F}$ & $\operatorname{Pr}>\mathrm{F}$ & $\mathbf{F}$ & $\operatorname{Pr}>\mathrm{F}$ & $\mathbf{F}$ & $\operatorname{Pr}>\mathrm{F}$ & $\mathbf{F}$ & $\operatorname{Pr}>\mathrm{F}$ & $\mathbf{F}$ & $\operatorname{Pr}>\mathrm{F}$ \\
\hline Model & 17 & 10.20 & $<0.0001$ & 10.23 & $<0.0001$ & 13.10 & $<0.0001$ & 10.71 & $<0.0001$ & 10.53 & $<0.0001$ & 10.69 & $<0.0001$ & 13.64 & $<0.0001$ & 10.45 & $<0.0001$ & 10.22 & $<0.0001$ \\
\hline Season & 2 & 77.92 & $<0.0001$ & 72.59 & $<0.0001$ & 111.77 & $<0.0001$ & 89.24 & $<0.0001$ & 66.97 & $<0.0001$ & 63.88 & $<0.0001$ & 42.74 & $<0.0001$ & 66.78 & $<0.0001$ & 73.10 & $<0.0001$ \\
\hline Treatment & 2 & 7.34 & 0.0060 & 12.56 & 0.0006 & 8.89 & 0.0028 & 1.35 & 0.2890 & 20.26 & $<0.0001$ & 23.63 & $<0.0001$ & 61.58 & $<0.0001$ & 19.05 & $<0.0001$ & 12.09 & 0.0007 \\
\hline Season $*$ Treatment & 4 & 3.24 & 0.0419 & 2.41 & 0.0951 & 11.46 & 0.0002 & 5.75 & 0.0052 & 1.88 & 0.1662 & 1.63 & 0.2186 & 2.26 & 0.1107 & 1.79 & 0.1842 & 2.48 & 0.0886 \\
\hline
\end{tabular}

The bold values indicate the statistical significance for Season ${ }^{\star}$ Treatment.

TABLE 3 | Analyses for marketable yield and nutritional content of water spinach under colored poly-net house, white poly-net house, and open field conditions in Taiwan during $2020-2021$.

\begin{tabular}{|c|c|c|c|c|c|c|c|c|c|c|c|c|c|c|c|c|c|c|c|}
\hline \multirow[t]{2}{*}{ Source } & \multirow[t]{2}{*}{ df } & \multicolumn{2}{|c|}{ Yield } & \multicolumn{2}{|c|}{ Dry matter } & \multicolumn{2}{|c|}{$\mathrm{Fe}$} & \multicolumn{2}{|c|}{ Violaxanthin } & \multicolumn{2}{|c|}{ Neoxanthin } & \multicolumn{2}{|c|}{ Lutein } & \multicolumn{2}{|c|}{$\alpha$-Carotene } & \multicolumn{2}{|c|}{ B-Carotene } & \multicolumn{2}{|c|}{$A O A$} \\
\hline & & $\mathbf{F}$ & $\operatorname{Pr}>F$ & $\mathbf{F}$ & $\operatorname{Pr}>F$ & $\mathbf{F}$ & $\operatorname{Pr}>F$ & $\mathbf{F}$ & $\operatorname{Pr}>F$ & $\mathbf{F}$ & $\operatorname{Pr}>F$ & $\mathbf{F}$ & $\operatorname{Pr}>F$ & $\mathbf{F}$ & $\operatorname{Pr}>\mathrm{F}$ & $\mathbf{F}$ & $\operatorname{Pr}>\mathrm{F}$ & $\mathbf{F}$ & $\operatorname{Pr}>\mathrm{F}$ \\
\hline Model & 17 & 12.24 & $<0.0001$ & 13.01 & $<0.0001$ & 33.67 & $<0.0001$ & 14.32 & $<0.0001$ & 19.01 & $<0.0001$ & 17.86 & $<0.0001$ & 31.29 & $<0.0001$ & 17.04 & $<0.0001$ & 18.64 & $<0.0001$ \\
\hline Season & 2 & 35.02 & $<0.0001$ & 38.30 & $<0.0001$ & 46.05 & $<0.0001$ & 32.33 & $<0.0001$ & 26.38 & 0.0002 & 27.34 & 0.0001 & 17.95 & 0.0007 & 31.09 & $<0.0001$ & 46.14 & $<0.0001$ \\
\hline Treatment & 2 & 12.40 & 0.0005 & 6.13 & 0.0099 & 140.96 & $<0.0001$ & 38.34 & 0.1100 & 96.26 & $<0.0001$ & 83.34 & $<0.0001$ & 218.97 & $<0.0001$ & 63.79 & $<0.0001$ & 20.42 & $<0.0001$ \\
\hline Season $*$ Treatment & 4 & 22.13 & $<0.0001$ & 25.18 & $<0.0001$ & 35.11 & $<0.0001$ & 18.19 & $<0.0001$ & 12.38 & $<0.0001$ & 13.22 & 0.0005 & 6.36 & 0.0026 & 16.90 & $<0.0001$ & 34.88 & $<0.0001$ \\
\hline
\end{tabular}

The bold values indicate the statistical significance for Season*Treatment. 
RDI value of $8 \mathrm{mg} /$ day (for men $19+$ and women $51+$ ) and 18 $\mathrm{mg} /$ day (for women 19-50) for iron was used in the estimation. The revised bio-efficacy of $\beta$-carotene in a mixed diet is $1: 12$, whereas it is 1:24 for other pro-vitamin A carotenoids (Institute of Medicine, 2001). The widely accepted recommended dietary allowance (RDA) for vitamin A is $900 \mu \mathrm{g}$ RAE for men (14+) and $700 \mu \mathrm{g}$ RAE for women (14+), except the pregnant and lactating women. Thus, it has been estimated to be $10.8 \mathrm{mg} /$ day $\beta$-carotene that would fulfill the RDA for vitamin A $(900 \mu \mathrm{g})$ for healthy men and $8.4 \mathrm{mg} /$ day for healthy women $(700 \mu \mathrm{g})$ (Böhm et al., 2020). Hence, these RDI/RDA values for iron and $\beta$-carotene were used to estimate the number of people that can receive these nutrients from the crop harvests in the current study.

\section{Data Analysis}

The data was analyzed using ANOVA with the procedure Proc GLM of SAS version 9.4 (SAS Institute, Cary, NC, USA). The significant differences were identified and means were separated by Tukey's HSD test (differences were considered significant at $\alpha=0.05$ ). Data on spider mite infestation did not follow normal distribution (even with data transformation). Therefore, a non-parametrical analysis was conducted. Each season was independently analyzed/crop, using the NPAR1WAY Procedure in SAS. Distribution of Wilcoxon Scores for spider mite percentages was analyzed with a Kruskal-Wallis Test. Later, a pairwise Two-Sided Multiple Comparison Analysis Dwass-Steel-Critchlow-Fligner Method was conducted to get differences between specific treatments per season/crop. For aphid infestation, categorical data was analyzed using the CATMOD procedure in SAS and the analysis of variance and the Analysis of Weighted Least Squares Estimates was done using a Chi-Square test for the treatment parameter. Data on diseases was transformed ASIN[SQRT(x)] for normality and UNIVARIATE Procedure was conducted to confirmed data had a fitted normal distribution following a Shapiro-Wilk test for normality. Combined analysis was conducted to evaluate differences among seasons in each crop. Non-transformed data is presented in the results section.

\section{RESULTS}

\section{Marketable Yield of Amaranth and Water Spinach}

Interaction effects (Treatment*Season) showed significant difference for marketable yield (Tables 1-3). White amaranth yield was significantly higher under pink poly-net house (19.70 $\mathrm{t} / \mathrm{ha}$ ) in the fall season, followed by open field (19.30 t/ha) and the white poly-net house $(17.88 \mathrm{t} / \mathrm{ha})$, which were on par with each other (Figure 1A). The yield was generally lower in the winter season compared to the fall season. In winter, both the pink poly-net house $(15.10 \mathrm{t} / \mathrm{ha})$ and the white poly-net house (15.30 t/ha) recorded similar yield, but it was significantly lower in the open field conditions (5.70 t/ha). Among the three seasons, spring recorded the lowest marketable yield in all the three production conditions. Like winter, both the pink poly-net house $(9.75 \mathrm{t} / \mathrm{ha})$ and the white poly-net house $(9.83 \mathrm{t} / \mathrm{ha})$ recorded similar yield, but nothing was harvested from the open field conditions.

The yield of red amaranth was also significantly higher under pink poly-net house (16.95 t/ha) in the fall season, followed by open field (13.50 t/ha) and the white poly-net house (13.45 $\mathrm{t} / \mathrm{ha}$ ), which were on par with each other (Figure 1B). Unlike white amaranth, the yield of red amaranth was slightly higher in the winter season compared to the fall season. In winter also, the poly-net houses recorded significantly higher yield (up to $18.17 \mathrm{t} / \mathrm{ha}$ ), followed by the open field conditions (16.90 t/ha). Spring recorded the lowest marketable yield in all the three production conditions. Both the pink poly-net house $(7.68 \mathrm{t} / \mathrm{ha})$ and the white poly-net house $(8.37 \mathrm{t} / \mathrm{ha})$ recorded similar yield, but nothing was harvested from the open field conditions.

In the fall season, both open field $(17.84 \mathrm{t} / \mathrm{ha})$ and the white poly-net house (16.25 t/ha) recorded higher yield of water spinach than the pink poly-net house (14.80 t/ha) (Figure 1C). However, in the winter, this crop yielded significantly higher only under the white poly-net house conditions (19.70 t/ha), followed by pink poly-net house (16.07 t/ha), but the harvest from the open field was much lower $(6.93 \mathrm{t} / \mathrm{ha})$. In contrary to the amaranth crops, water spinach yielded significantly higher during the spring season. The yield was similar in all the three production conditions and ranged $20.55-20.88 \mathrm{t} / \mathrm{ha}$.

\section{Pests and Diseases}

Spider mite (Tetranychus spp.) appeared to be the predominant pest on all the three crops in the poly-net houses, irrespective of their color in the fall and spring seasons (Figure 2). However, open-field water spinach was also infested by the mites in the fall season. Aphids were recorded as the major pest in the winter crop. About $77.5 \%$ of the red amaranth (Chi-square $=431.38, P$ $<0.0001$ ) and $100 \%$ of the white amaranth (Chi-square $=88.40$, $P<0.0001)$ in white poly-net house had reached the damage score of 5 , whereas it was $75 \%$ in both red amaranth and white amaranth plants in the pink poly-net house condition (Figure 3). Although $30 \%$ of the red amaranth in open field condition were mildly (1-2 score) infested by aphids, the white amaranth was completely free from aphid infestation. Similarly, a vast majority of water spinach plants $(72.5 \%)$ were free from aphids (Chisquare $=352.16, P<0.0001)$, but about $87.5 \%$ of plants in the white poly-net house and about $75 \%$ of plants in the pink poly-net house were infested by aphids. There was no disease infecting the water spinach. However, white and red amaranths were infected by Pythium and Rhizoctonia. Interaction effects (Treatment*Season) showed significant difference for disease incidence on white amaranth, but not on red amaranth (Table 4). The disease was comparatively severe on white amaranth than on red amaranth (Table 5), but more or less similar in all the three production conditions, with the maximum incidence of $7.55 \%$ during the fall season.

\section{Nutritional Content}

Interaction effects (Treatment*Season) showed significant difference for all the nutritional parameters of white amaranth (Table 1). The dry matter content was corresponding to the yield of the crop under different production conditions (Table 6). 


\section{A White amaranth}

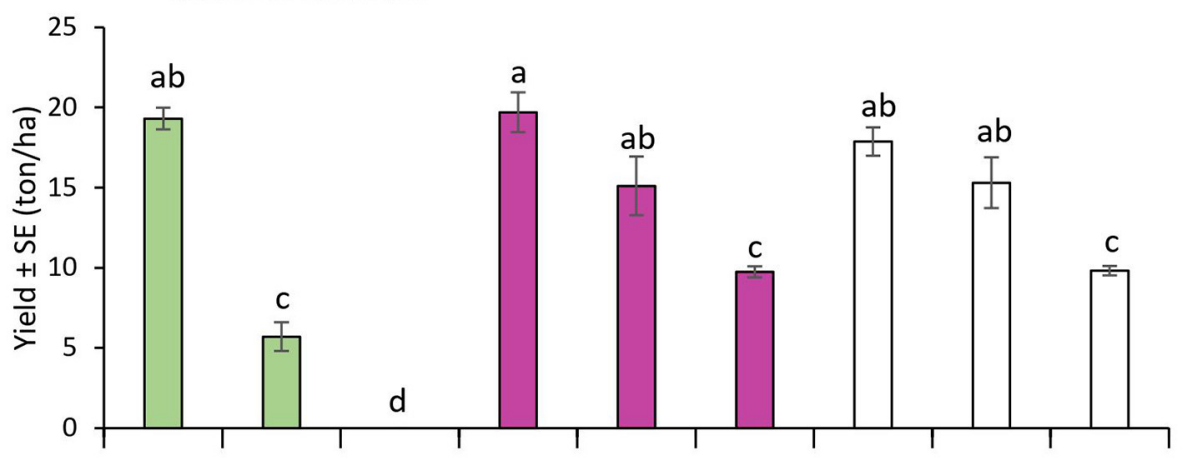

B Red amaranth

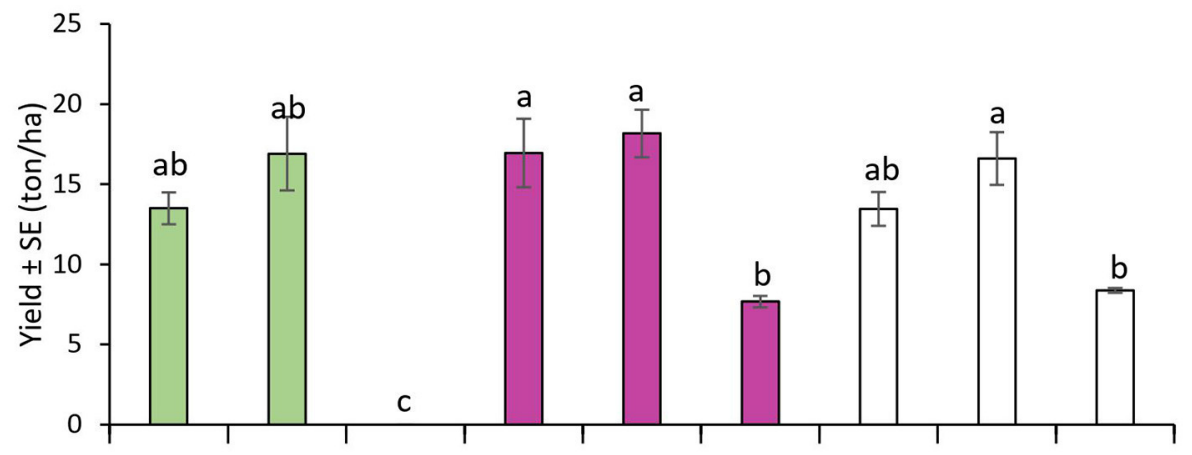

c Water spinach

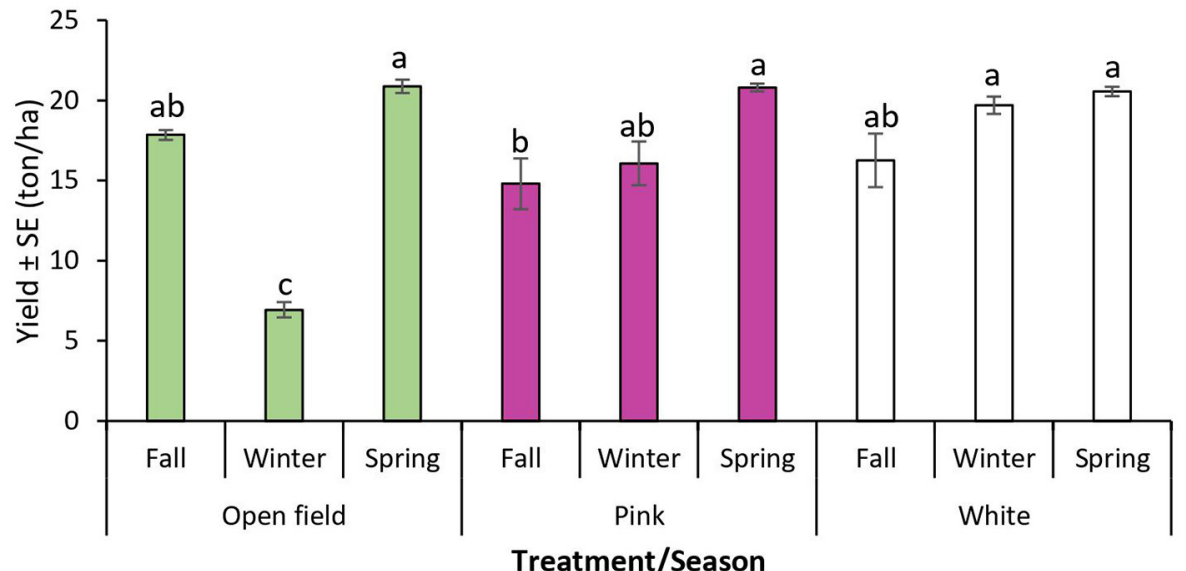

FIGURE 1 | Yield \pm SE (ton/ha) of leafy vegetables grown under different production conditions. (A) White amaranth, (B) Red amaranth, (C) Water spinach. Means represent average of four replications in each treatment/season. Means followed by the same letter(s) in a crop are not significantly different $(p<0.05)$.

The iron content was significantly higher during the fall season in the white amaranth harvested from the open field (881.67 $\mathrm{g} / \mathrm{ha}$ ), followed by pink poly-net house (336.48 g/ha) and white poly-net house $(234.50 \mathrm{~g} / \mathrm{ha})$. However, the open field (260.39 $\mathrm{g} / \mathrm{ha}$ ) and the pink poly-net house (257.91 g/ha) supplied more iron than the white poly-net house $(200.72 \mathrm{~g} / \mathrm{ha})$ in the winter season. Since no crop was harvested from the open field during the spring season, there was no iron supply from the open field condition. However, both the poly-net houses yielded similar amount of iron (128.89-166.53 g/ha) during the spring. Although open field production of white amaranth supplied better violaxanthin, neoxanthin and lutein in the fall season, it fell behind the poly-net houses in the winter crop. Supply of these compounds from the pink poly-net house was 
Fall Season
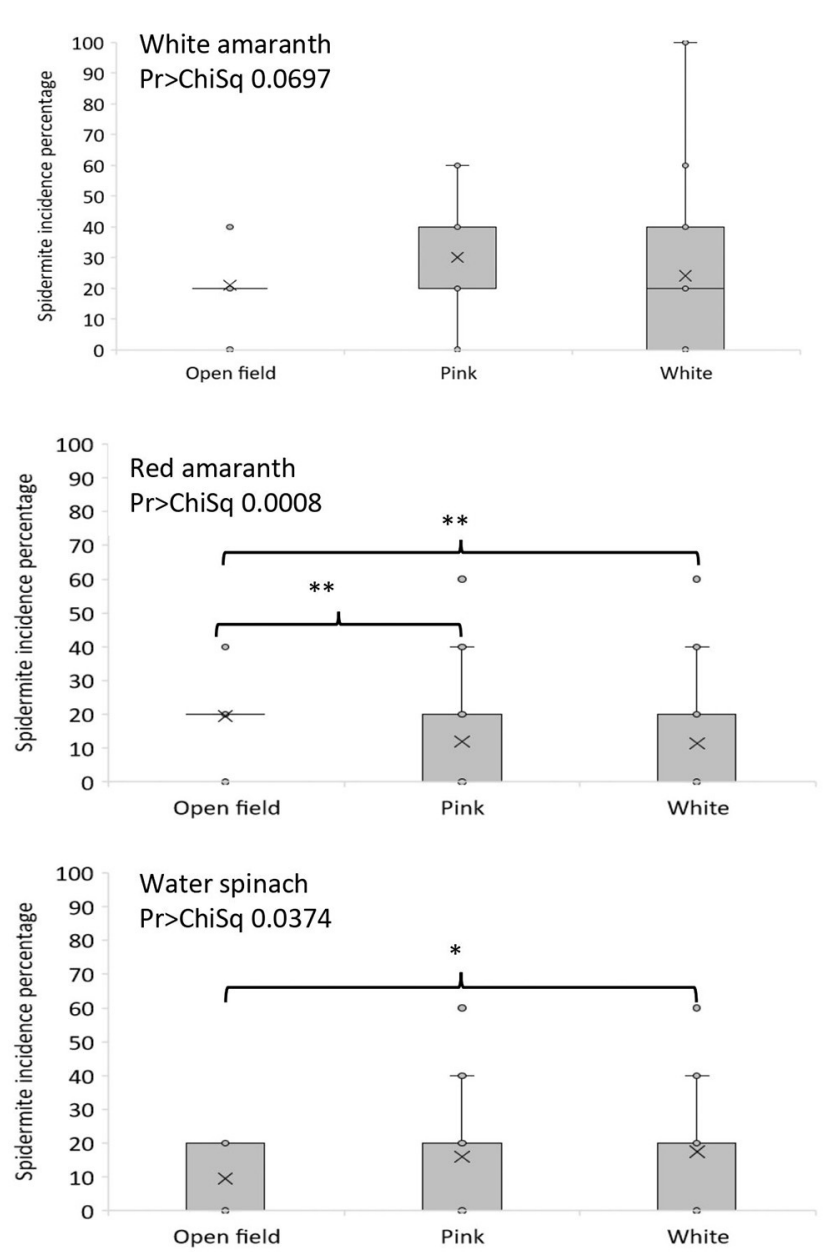

Spring Season
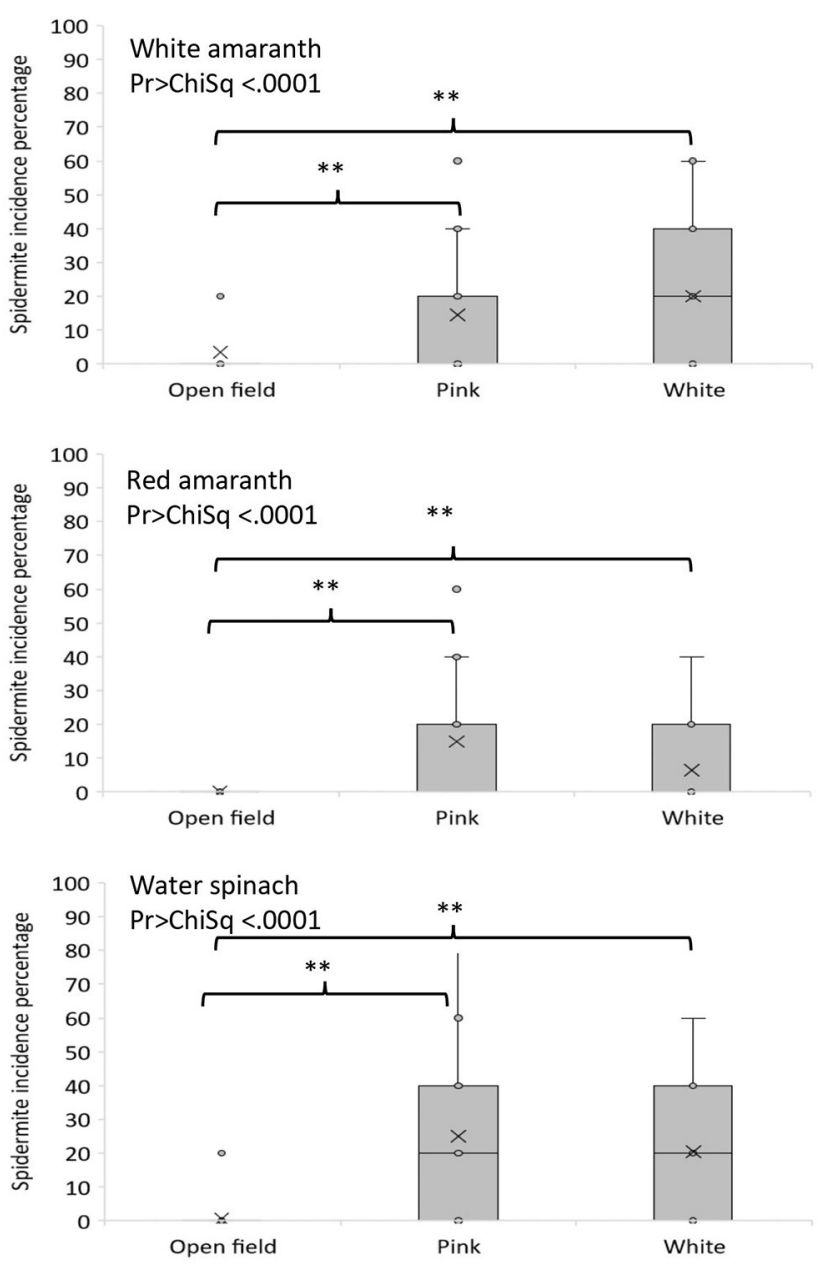

Treatments

FIGURE 2 | Mean ( \pm SD) incidence of spider mite (Tetranychus spp.) on leafy vegetables grown under different production conditions. (A) White amaranth, (B) Red amaranth, (C) Water spinach. Means represent average of four replications in each treatment/season. *significant; *kighly significant.

significantly higher than from the white poly-net house in both fall and winter crops. Similarly, both the poly-net houses provided significantly higher amount of $\alpha$-Carotene (18.90$47.18 \mathrm{~g} / \mathrm{ha})$ and $\beta$-Carotene $(362.32-732.06 \mathrm{~g} / \mathrm{ha})$ than the open field crops (0-16.06 g/ha and 0-556.29 g/ha) during these seasons. Consistently, better anti-oxidant activity was recorded for both the poly-net houses (91.68-190.24 mole/ha) than the open field (0-165.43 mole/ha) in the fall and winter seasons. However, all the nutritional parameters were significantly higher in both the poly-net houses than in the open field during the spring season.

Interaction effects (Treatment*Season) showed significant difference only for iron and violaxanthin content of red amaranth (Table 2). The iron content was significantly higher in red amaranth produced from open field (645.42 $\mathrm{g} / \mathrm{ha})$, compared to the white poly-net house $(352.14 \mathrm{~g} / \mathrm{ha})$ during the fall season (Table 7). However, it was intermediate in the crop produced from the pink poly-net house (574.04 $\mathrm{g} / \mathrm{ha}$ ). Similar trend was also recorded in the winter season. The violaxanthin supply was almost on par in all the treatments in both fall (798.47-954.43 g/ha) and winter (985.47-1178.38 g/ha) seasons. In red amaranth as well, there was no supply of iron and violaxanthin from open field production during spring, but both the poly-net houses provided equal amounts (432.31-496.74 g/ha). In addition, dry matter content, carotenoids and anti-oxidant activity of red amaranth only responded to treatment effect (Table 8). Moreover, pink poly-net house recorded significantly higher amount of all the other nutritional compounds (Table 8). White poly-net house also recorded on par values for most of the parameters, except for neoxanthin, lutein and $\alpha$-Carotene. All these nutritional compounds were significantly lower in red amaranth harvested from the open field, compared to the polynet houses. 

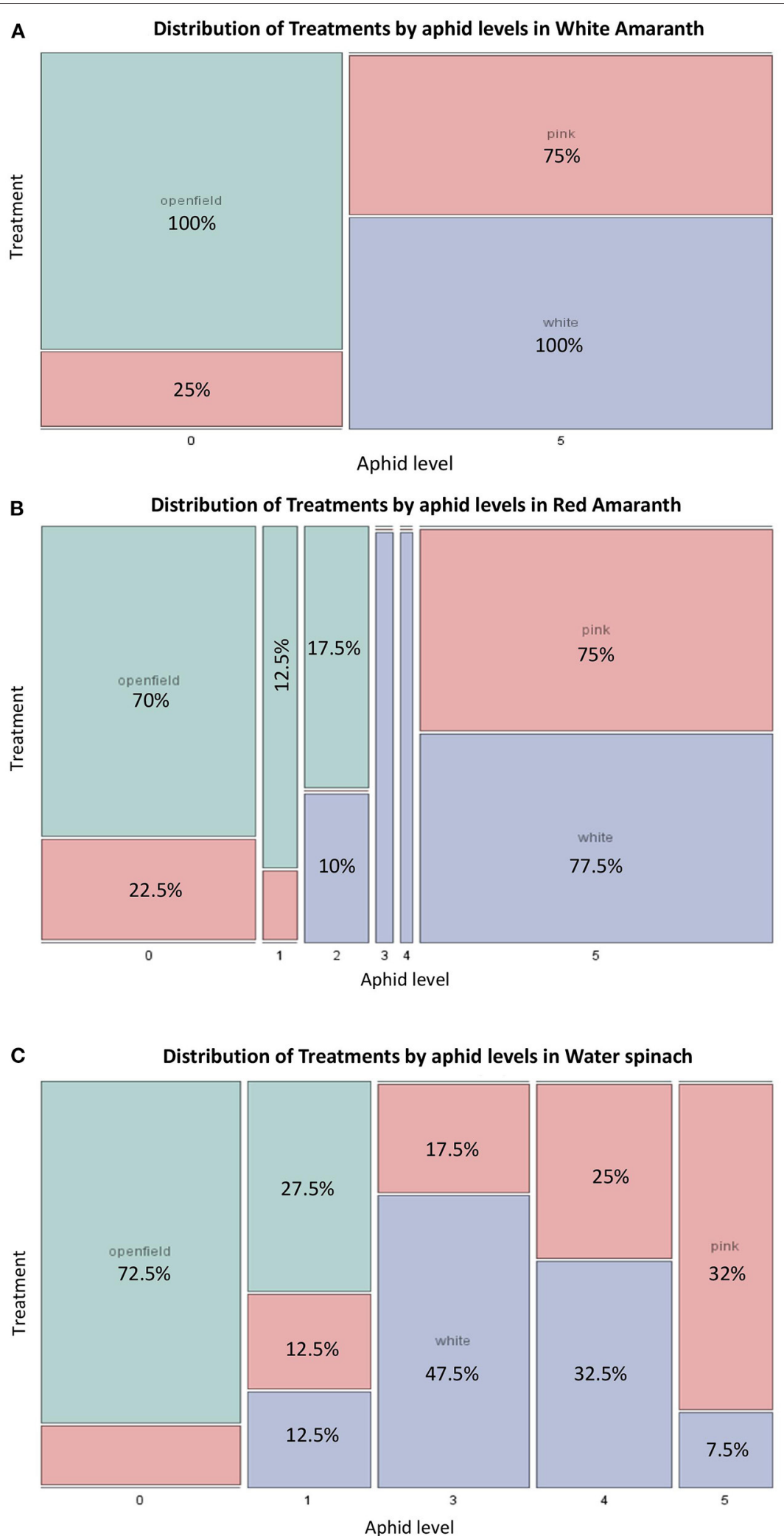

FIGURE 3 | Mean incidence of aphids on leafy vegetables grown under different production conditions. (A) White amaranth, (B) Red amaranth, (C) Water spinach. Means represent average of four replications in each treatment/season. 
TABLE 4 | Analyses for disease incidence on white amaranth and red amaranth under colored poly-net house, white poly-net house, and open field conditions in Taiwan during 2020-2021.

\begin{tabular}{llllllc}
\hline Source & df & \multicolumn{2}{c}{ White Amaranth } & & \multicolumn{2}{c}{ Red Amaranth } \\
\cline { 3 - 4 } & & F & Pr $>$ F & & F & Pr $>$ F \\
\hline Model & 17 & 43.12 & $<0.0001$ & & 1.02 & 0.48 \\
Season & 2 & 21.48 & 0.0004 & & 8.58 & 0.0082 \\
Treatment & 2 & 97.44 & $<0.0001$ & & 3.42 & 0.0578 \\
Season*Treatment & 4 & 49.09 & $<0.0001$ & & 1.20 & 0.3504 \\
\hline
\end{tabular}

TABLE 5 | Disease incidence (\%) on white amaranth and red amaranth under colored poly-net house, white poly-net house, and open field conditions in Taiwan during 2020-2021.

\begin{tabular}{|c|c|c|c|c|c|}
\hline \multirow[t]{2}{*}{ Season } & \multirow[t]{2}{*}{ Treatment } & \multicolumn{2}{|c|}{ White Amaranth } & \multicolumn{2}{|r|}{ Red Amaranth } \\
\hline & & $\mathbf{N}$ & $\begin{array}{c}\text { Disease } \\
\text { percentage } \pm S E\end{array}$ & $\mathbf{N}$ & $\begin{array}{c}\text { Disease } \\
\text { percentage } \pm \text { SE }\end{array}$ \\
\hline \multirow[t]{3}{*}{ Fall } & Open field & 4 & $6.37 \pm 1.23 \mathrm{ab}$ & 4 & $1.80 \pm 0.22$ \\
\hline & Pink & 4 & $7.55 \pm 1.14 \mathrm{a}$ & 4 & $1.94 \pm 0.15$ \\
\hline & White & 4 & $7.55 \pm 1.14 \mathrm{a}$ & 4 & $2.24 \pm 1.04$ \\
\hline \multirow[t]{3}{*}{ Winter } & Open field & 4 & $\mathrm{Oe}$ & 4 & 0.00 \\
\hline & Pink & 4 & $3.96 \pm 0.63 \mathrm{~cd}$ & 4 & $2.37 \pm 0.90$ \\
\hline & White & 4 & $4.63 \pm 0.53 \mathrm{bc}$ & 4 & $1.32 \pm 0.79$ \\
\hline \multirow[t]{3}{*}{ Spring } & Open field & 4 & $2.86 \pm 0.24 d$ & 4 & $0.83 \pm 0.10$ \\
\hline & Pink & 4 & $3.04 \pm 0.13 d$ & 4 & $1.92 \pm 0.07$ \\
\hline & White & 4 & $3.40 \pm 0.05 \mathrm{~cd}$ & 4 & $1.84 \pm 0.26$ \\
\hline
\end{tabular}

Means followed by the same letter(s) in a column are not significantly different $(p<0.05)$.

Interaction effects (Treatment*Season) showed significant difference for all the nutritional parameters of water spinach (Table 3). The dry matter content was significantly higher in the water spinach harvested from the open field during fall season $(2,128.6 \mathrm{~kg} / \mathrm{ha})$, but it was the lowest in the winter season (826.2 kg/ha) (Table 9). In spring, the dry matter content was significantly higher in the plants harvested from pink polynet house $(2,520.7 \mathrm{~kg} / \mathrm{ha})$, followed by the open field $(2,490.6$ $\mathrm{kg} / \mathrm{ha}$ ). The iron content was significantly higher during the fall season in the water spinach harvested from the open field (361.7 $\mathrm{g} / \mathrm{ha}$ ), followed by pink poly-net house (298.4 g/ha), but only the pink poly-net house supplied more iron (323.9 g/ha) than the other two production conditions (140.4-168.3 g/ha) in the winter season. Both the open field condition (423.2 g/ha) and the pink poly-net house (419.3 g/ha) yielded significantly higher amount of iron during the spring. Consistently higher number of carotenoids were obtained from the water spinach harvested under the pink poly-net house in all the seasons, and it was significantly higher during the spring than the other seasons. Significantly higher anti-oxidant activity was recorded for the open field in the fall (336.3 mole/ha) and spring (393.4 mole/ha) seasons, which was on par with the pink poly-net house (344.5 mole/ha) in the spring.

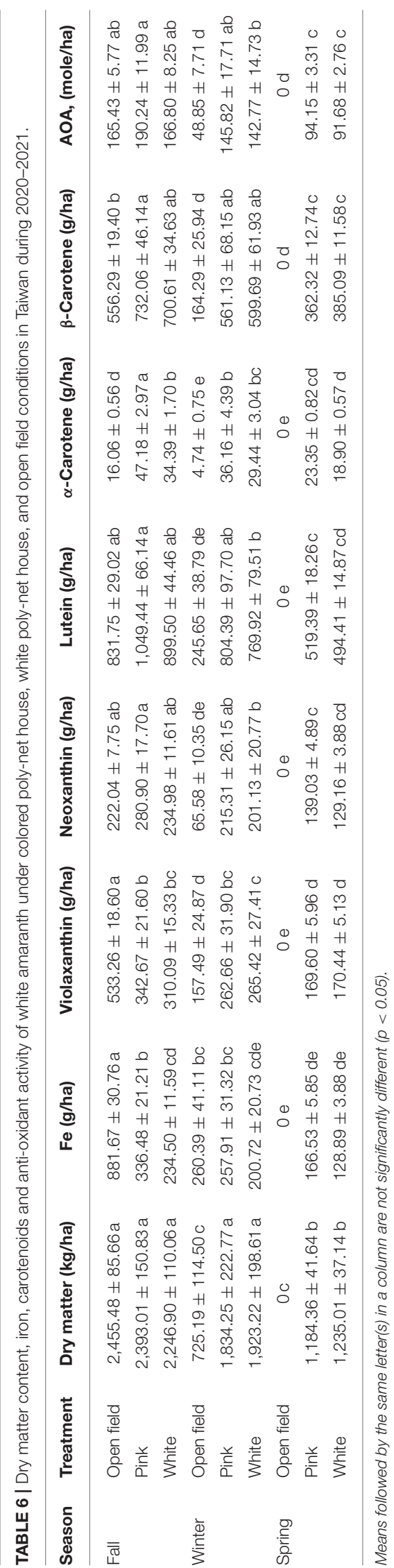




\section{Number of People That Can Receive Recommended Dietary Intake of Iron and $\beta$-Carotene}

Based on the widely accepted RDI of iron, open field produced white amaranth from a hectare was estimated to supply iron to $68,149-80,896$ more men (19+ years old) and women (51+ years old) than the crop produced under poly-net houses during the fall season (Table 10). In the winter, the white amaranth produced from the open field conditions as well as the pink poly-net houses was estimated to supply iron to almost equal number $(>7,000$ people) of men and women $(51+)$. In addition, water spinach produced under the pink poly-net houses during winter was estimated to provide iron to 19,450-22,939 more men $(19+)$ and women $(51+)$ than the other production conditions. In the spring, the white and red amaranths produced under poly net-houses supplied the iron, and the pink poly-net house was estimated to supply to 2,000-5,000 more men and women than the white poly-net house. In case of women (19-50 years), the same trend in the results was also recorded for all the crops, seasons and production conditions. $\beta$-Carotene supply to both men $(14+)$ and women (14+) was consistently higher in all the crops produced under the pink ploy-net houses in all the seasons, except for the white amaranths produced under white poly-net house during the winter. The maximum supply from the red amaranth produced under pink poly-net houses reached a value of 64,788 more men and 83,298 more women than the other production conditions in all the seasons (Table 10). Thus, the pink poly-net house was found to be the most suitable

TABLE 7 | Iron and violaxanthin content of red amaranth under colored poly-net house, white poly-net house, and open field conditions in Taiwan during 2020-2021.

\begin{tabular}{llcc}
\hline Season & Treatment & Fe (g/ha) & Violaxanthin $(\mathbf{g} / \mathbf{h a})$ \\
\hline Fall & Open field & $645.42 \pm 47.61 \mathrm{ab}$ & $941.31 \pm 69.44 \mathrm{a}$ \\
& Pink & $574.04 \pm 72.43 \mathrm{abc}$ & $954.43 \pm 120.43 \mathrm{a}$ \\
\multirow{3}{*}{ Winter } & White & $352.14 \pm 27.55 \mathrm{~cd}$ & $798.47 \pm 62.48 \mathrm{ab}$ \\
& Open field & $807.97 \pm 109.96 \mathrm{a}$ & $1,178.38 \pm 160.37 \mathrm{a}$ \\
& Pink & $615.25 \pm 50.39 \mathrm{abc}$ & $1,022.94 \pm 83.79 \mathrm{a}$ \\
\multirow{3}{*}{ Spring } & White & $434.61 \pm 43.02 \mathrm{bcd}$ & $985.47 \pm 97.55 \mathrm{a}$ \\
& Open field & $0 \mathrm{e}$ & $0 \mathrm{c}$ \\
& Pink & $260.01 \pm 11.89 \mathrm{~d}$ & $432.31 \pm 19.78 \mathrm{~b}$ \\
& White & $219.07 \pm 3.84 \mathrm{~d}$ & $496.74 \pm 8.72 \mathrm{~b}$ \\
\hline
\end{tabular}

Means followed by the same letter(s) in a column are not significantly different $(p<0.05)$. production condition for supplying $\beta$-Carotene to a maximum number of people.

\section{DISCUSSION}

In this study, we investigated the effect of different colored polynet house compared to open field conditions in terms of yield, dry matter content, iron, carotenoids and anti-oxidant activity for three leafy vegetables, viz., white amaranth, red amaranth, and water spinach, over three seasons (fall, winter and spring). In addition, the overall effect of pests and diseases was also evaluated under the above-mentioned conditions. Finally, the number of people who could receive selected micro-nutrients from the crops harvested under different production conditions was estimated based on the RDI values. This is quite important to understand if sufficient quantity of nutrient-dense vegetables can be grown in a relatively small area, considering the context of fast shrinking farmlands. To our knowledge, there are not many scientific information available on this perspective.

Generally, the amaranth yield was higher in the fall season, which could be due to the higher prevailing temperature during this season, ranging between 25.7 and $27.2^{\circ} \mathrm{C}$ (Table 11). An increased temperature (from 28 to $32^{\circ} \mathrm{C}$ ) was found to promote both root and leaf growth in edible amaranth (A. tricolor cv. White leaf) in Taiwan (Hwang et al., 2018). Amaranth is a C4 plant, and an earlier study had demonstrated that photorespiration losses in C4 plants were limited and hence C4 plants had higher net photosynthetic rates at higher temperatures compared to C3 plants (Long, 1999). Hence, the higher temperature during the fall season was found to have a positive effect on the growth of this $\mathrm{C} 4$ crop. Besides temperature, the light conditions inside the poly-net houses were believed to have provided the optimum microclimate for growth and development of amaranth crops. For instance, the blue irradiance (400-500 nm) inside the pink net house was about $40 \%$, whereas it was about $25 \%$ in the white poly-net house and open field conditions. It was already demonstrated that the blue (400$450 \mathrm{~nm}$ ) polyethylene shade condition produced taller plant height, a greater number of leaves, biomass yield and bioactive compounds in red amaranth, compared with other conditions of films (Khandaker et al., 2010). This might be due to the fact that some plant species are more sensitive to blue light (Casal, 1994). Thus, the combination of higher temperature and blue light in the poly-net houses could have contributed for the better yield. Although both white and red amaranths are C4 plants, the yield of red amaranth was slightly higher in the winter season compared to the fall season, whereas it was not

TABLE 8 | Dry matter content, carotenoids and anti-oxidant activity of red amaranth under colored poly-net house, white poly-net house, and open field conditions in Taiwan during 2020-2021.

\begin{tabular}{|c|c|c|c|c|c|c|}
\hline Treatment & Dry matter (kg/ha) & Neoxanthin (g/ha) & Lutein (g/ha) & $\alpha$-Carotene (g/ha) & $\beta$-Carotene (g/ha) & AOA (mole/ha) \\
\hline Open field & $1,461.99 \pm 376.39 b$ & $484.94 \pm 124.85 c$ & $1,380.93 \pm 355.52 \mathrm{c}$ & $54.95 \pm 14.15 c$ & $723.69 \pm 186.31 b$ & $134.09 \pm 34.52 b$ \\
\hline Pink & $2,630.93 \pm 307.10 a$ & $1,015.99 \pm 118.59 a$ & $3,085.79 \pm 360.19 a$ & $241.31 \pm 28.17 \mathrm{a}$ & $1,487.38 \pm 173.62 \mathrm{a}$ & $238.84 \pm 27.88 \mathrm{a}$ \\
\hline White & $2,290.67 \pm 211.18 a$ & $815.31 \pm 75.17 b$ & $2,468.60 \pm 227.59 b$ & $166.28 \pm 15.33 b$ & $1,243.68 \pm 114.66 \mathrm{a}$ & $208.33 \pm 19.21 \mathrm{a}$ \\
\hline
\end{tabular}

Means followed by the same letter(s) in a column are not significantly different $(p<0.05)$. 
TABLE 9 | Dry matter content, iron, carotenoids and anti-oxidant activity of water spinach under colored poly-net house, white poly-net house, and open field conditions in Taiwan during 2020-2021.

\begin{tabular}{|c|c|c|c|c|c|c|c|c|c|}
\hline Season & Treatment & Dry matter (kg/ha) & $\mathrm{Fe}(\mathrm{g} / \mathrm{ha})$ & Violaxanthin (g/ha) & Neoxanthin (g/ha) & Lutein $(\mathrm{g} / \mathrm{ha})$ & $\alpha$-Carotene (g/ha) & $\beta$-Carotene $(\mathrm{g} / \mathrm{ha})$ & AOA (mole/ha) \\
\hline \multirow[t]{3}{*}{ Fall } & Open field & $2,128.6 \pm 37.3 \mathrm{abc}$ & $361.7 \pm 6.3 \mathrm{ab}$ & $502.2 \pm 8.8 \mathrm{bc}$ & $402.3 \pm 7.0 \mathrm{~d}$ & $1,142.0 \pm 20.0 c$ & $17.1 \pm 0.3 \mathrm{de}$ & $562.3 \pm 9.8 b c$ & $336.3 \pm 5.9 \mathrm{ab}$ \\
\hline & Pink & $1,793.5 \pm 192.2 \mathrm{~cd}$ & $298.4 \pm 32.0 \mathrm{~b}$ & $541.1 \pm 58.0 \mathrm{bc}$ & $581.2 \pm 62.3 \mathrm{bc}$ & $1,559.8 \pm 167.1 \mathrm{~b}$ & $49.0 \pm 5.2 b$ & $660.6 \pm 70.8 \mathrm{bc}$ & $245.1 \pm 26.3 c$ \\
\hline & White & $1,594.3 \pm 163.7 \mathrm{~d}$ & $138.8 \pm 14.2 \mathrm{c}$ & $409.9 \pm 42.1 c$ & $379.3 \pm 38.9 d$ & $1,055.0 \pm 108.3 c$ & $28.8 \pm 3.0 \mathrm{~cd}$ & $436.5 \pm 44.8 d$ & $195.2 \pm 20.0 \mathrm{cc}$ \\
\hline \multirow[t]{3}{*}{ Winter } & Open field & $826.2 \pm 56.9 \mathrm{e}$ & $140.4 \pm 9.7 c$ & $194.9 \pm 13.4 d$ & $156.1 \pm 10.7 \mathrm{e}$ & $443.2 \pm 30.5 d$ & $6.7 \pm 0.5 \mathrm{e}$ & $218.2 \pm 15.0 \mathrm{e}$ & $130.5 \pm 9.0 \mathrm{~d}$ \\
\hline & Pink & $1,947.0 \pm 166.9 \mathrm{bcd}$ & $323.9 \pm 27.8 b$ & $587.4 \pm 50.4 b$ & $631.0 \pm 54.1 \mathrm{~b}$ & $1,693.3 \pm 145.2 b$ & $53.2 \pm 4.6 b$ & $717.2 \pm 61.5 b$ & $266.1 \pm 22.8 \mathrm{bc}$ \\
\hline & White & $1,932.7 \pm 53.4 \mathrm{~cd}$ & $168.3 \pm 4.6 c$ & $497.0 \pm 13.7 \mathrm{bc}$ & $459.8 \pm 12.7 \mathrm{~cd}$ & $1,279.0 \pm 35.4 \mathrm{bc}$ & $34.9 \pm 1.0 c$ & $529.2 \pm 14.6 \mathrm{~cd}$ & $236.6 \pm 6.5 c$ \\
\hline \multirow[t]{3}{*}{ Spring } & Open field & $2,490.6 \pm 50.5 \mathrm{ab}$ & $423.2 \pm 8.6 \mathrm{a}$ & $587.6 \pm 11.9 b$ & $470.7 \pm 9.5 \mathrm{bcd}$ & $1,336.1 \pm 27.1 \mathrm{bc}$ & $20.1 \pm 0.4 d$ & $657.9 \pm 13.3 \mathrm{bc}$ & $393.4 \pm 8.0 \mathrm{a}$ \\
\hline & Pink & $2,520.7 \pm 30.1 a$ & $419.3 \pm 5.0 \mathrm{a}$ & $760.5 \pm 9.1 \mathrm{a}$ & $816.9 \pm 9.7 a$ & $2,192.1 \pm 26.2 \mathrm{a}$ & $68.9 \pm 0.8 a$ & $928.4 \pm 11.1 \mathrm{a}$ & $344.5 \pm 4.1 \mathrm{a}$ \\
\hline & White & $2,016.1 \pm 28.5 \mathrm{bcd}$ & $175.6 \pm 2.5 c$ & $518.4 \pm 7.3 \mathrm{bc}$ & $479.6 \pm 6.8 \mathrm{bc}$ & $1,334.2 \pm 18.8 \mathrm{bc}$ & $36.4 \pm 0.5 c$ & $552.0 \pm 7.8 \mathrm{bcd}$ & $246.8 \pm 3.5 c$ \\
\hline
\end{tabular}

Means followed by the same letter(s) in a column are not significantly different $(p<0.05)$.

TABLE 10 | Number of people that can receive recommended daily intake of iron and $\beta$-Carotene from white amaranth, red amaranth and water spinach grown under colored poly-net house, white poly-net house, and open field conditions in Taiwan during 2020-2021.

\begin{tabular}{|c|c|c|c|c|c|c|c|c|c|c|c|c|c|}
\hline \multirow[t]{3}{*}{ Season } & \multirow[t]{3}{*}{ Treatment } & \multicolumn{6}{|c|}{ Iron } & \multicolumn{6}{|c|}{$\beta$-Carotene } \\
\hline & & \multicolumn{2}{|c|}{ White amaranth } & \multicolumn{2}{|c|}{ Red amaranth } & \multicolumn{2}{|c|}{ Water spinach } & \multicolumn{2}{|c|}{ White amaranth } & \multicolumn{2}{|c|}{ Red amaranth } & \multicolumn{2}{|c|}{ Water spinach } \\
\hline & & $\begin{array}{c}\text { Men }(>19) \text { \& } \\
\text { Women }(>51)\end{array}$ & $\begin{array}{l}\text { Women } \\
(19-50)\end{array}$ & $\begin{array}{c}\text { Men }(>19) \& \\
\text { Women }(>51)\end{array}$ & $\begin{array}{l}\text { Women } \\
(19-50)\end{array}$ & $\begin{array}{c}\text { Men }(>19) \& \\
\text { Women }(>51)\end{array}$ & $\begin{array}{l}\text { Women } \\
(19-50)\end{array}$ & Men $(>14)$ & $\begin{array}{c}\text { Women } \\
(>14)\end{array}$ & Men (>14) & $\begin{array}{c}\text { Women } \\
(>14)\end{array}$ & Men $(>14)$ & $\begin{array}{c}\text { Women } \\
(>14)\end{array}$ \\
\hline \multirow[t]{3}{*}{ Fall } & Open field & 110,209 & 48,982 & 80,678 & 35,857 & 45,218 & 20,097 & 51,508 & 66,225 & 103,031 & 132,469 & 52,064 & 66,939 \\
\hline & Pink & 42,060 & 18,693 & 71,755 & 31,891 & 37,298 & 16,577 & 67,783 & 87,150 & 167,819 & 215,767 & 61,169 & 78,645 \\
\hline & White & 29,313 & 13,028 & 44,018 & 19,563 & 17,355 & 7,713 & 64,871 & 83,406 & 120,948 & 155,505 & 40,416 & 51,963 \\
\hline \multirow[t]{3}{*}{ Winter } & Open field & 32,549 & 14,466 & 100,996 & 44,887 & 17,551 & 7,801 & 15,212 & 19,558 & 128,981 & 165,832 & 20,208 & 25,982 \\
\hline & Pink & 32,239 & 14,328 & 76,906 & 34,181 & 40,490 & 17,996 & 51,956 & 66,801 & 179,865 & 231,255 & 66,404 & 85,376 \\
\hline & White & 25,090 & 11,151 & 54,326 & 24,145 & 21,040 & 9,351 & 55,527 & 71,392 & 149,275 & 191,925 & 48,997 & 62,996 \\
\hline \multirow[t]{3}{*}{ Spring } & Open field & 0 & 0 & 0 & 0 & 52,906 & 23,514 & 0 & 0 & 0 & 0 & 60,917 & 78,321 \\
\hline & Pink & 20,816 & 9,252 & 32,501 & 14,445 & 52,419 & 23,297 & 33,548 & 43,133 & 76,014 & 97,732 & 85,967 & 110,529 \\
\hline & White & 16,111 & 7,161 & 27,384 & 12,171 & 21,948 & 9,754 & 35,656 & 45,844 & 75,244 & 96,743 & 51,111 & 65,714 \\
\hline
\end{tabular}


the case for white amaranth. Hence, besides temperature and light conditions, other factors may also contribute to these yield differences across the seasons. For instance, the photosynthetic pigments of higher plants include chlorophyll and carotenoids. The carotenoids content of the red amaranth were higher than the white amaranth, and most of the carotenoids in the white amaranth were lower in the winter season than in the fall. Hence, future studies should elucidate the role of photosynthetic pigments on yield under different production systems across the growing seasons. In addition, comparatively lower yield in the spring season, despite the warmer temperature could have been attributed to the higher spider mite infestation during this season. The growth and performance of water spinach was relatively better in the poly-net houses in all the seasons compared to the open field conditions, in which the lowest yield was recorded in the winter. Water spinach has originated from tropical regions, with high tolerance to heat and wet (Liou, 1981). The optimal growth conditions are temperatures between 20 and $27^{\circ} \mathrm{C}$ and the humidity of above $75 \%$ (Pinker et al., 2007). Since the winter temperature was quite low (Table 11), especially in the open field conditions, the yield might have declined significantly.

It is not surprising to record the spider mite infestation during the fall and spring season, in which the temperature is relatively warmer than the cold winter in Taiwan (Table 11). Most spider mites prefer warm and dry conditions. Although spider mite populations are found on crops in winter months in Taiwan (Ho, 2000), we did not find mite infestation on both the amaranth varieties and water spinach during the winter season. This is also due to the fact that aphids emerged as a major pest during the winter months and hence they outcompete spider mites. Aphids have been recorded as a serious pest of amaranth (Ebert et al., 2011). In fact, aphids occurred highly inside the polynet houses. Several earlier studies have documented the aphid outbreaks inside the net house conditions (Talekar et al., 2003; Majumdar and Powell, 2011). A warm weather inside the polynet houses during the winter months and the absence of natural enemies inside the protective structures could have led to the proliferation of aphid infestation in the current study. The major entry point for aphids and mites is through the nylon net. Most net houses were built with 40 -mesh netting. The 40-mesh or coarser mesh nets failed to exclude the thrips, whitefly and aphid in several countries (Talekar et al., 2003; Harmanto, 2006). The poly-net houses used in the current study have been built with 32-mesh netting only. Hence, they were not able to prevent the entry of aphids and spider mites. The most promising way to prevent the entry of small-sized insects and mites in net houses is to use nets with finer mesh. Nets with 50 -mesh or 60 -mesh size to exclude thrips, whitefly, and aphids have been suggested (Polston and Lapidot, 2007; Shahak et al., 2008; Palada and $\mathrm{Wu}, 2009)$. However, finer mesh size reduces the ventilation rate and increases the relative humidity inside the net houses (Harmanto et al., 2006), which could favor the incidence of diseases, although it was not the case in the current study. It is interesting to note that the crop yields in both the poly-net houses were similar or higher than the open field production conditions despite the higher incidences of spider mite or aphids inside the poly-net houses. Hence, proper control options to manage aphids and spider mite on leafy vegetables in poly-net house conditions should be considered so that the crop productivity can be further increased.

Among the three production conditions compared in the current study, most of the carotenoids consistently occurred in higher quantities in the white amaranth crop produced under pink poly-net houses. Neoxanthin, lutein, and $\beta$-carotene were slightly higher in the red amaranth grown under the poly-net houses. Similarly, $\alpha$-carotene was also higher in the amaranth crops grown under the poly-net houses. A recent study conducted under open field conditions in the same location documented higher amounts of violaxanthin, neoxanthin and lutein (Nordey et al., 2021) than the white amaranth in the current study, but the $\alpha$ - and $\beta$-carotenes were similar in both the studies. However, all the carotenoids in the previous study were lower than the quantities in the red amaranth in our study. It should be noted that the previous study involved amaranth accessions from different species (Amaranthus hypochondriacus, A. cruentus, A. dubius and A. blitum), whereas the varieties in the current study belonged to A. tricolor. In line with this, other papers on amaranth studying the carotenoid profiles corroborated our results, where higher carotenoids in the red amaranth have been observed compared to other genotypes (Khanam and Oba, 2013; Sarker and Oba, 2020). Hence, the quantity of carotenoids not only differed among the species of amaranth, but also varied among the varieties within a species. In addition, these variations could be altered by the production conditions, as we observed in the case of red amaranth under poly-net house conditions compared to the open field conditions. Hence, protected cultivation conditions not only lead to more marketable yields but also result in higher quantities of health promoting nutrients.

The quantities of the carotenoids such as lutein and $\beta$-carotene observed in water spinach in the current study were similar to the earlier findings (Khoo et al., 2011; Chandra-Hioe et al., 2017), and the $\alpha$-carotene was 10-25-fold higher than an earlier report (Khoo et al., 2011). As observed in the case of amaranth crops, $\alpha$-carotene in water spinach was also two to three-fold higher in the crops harvested from the poly-net houses than the open field condition. The iron content of the amaranth varieties produced from the open field conditions was comparable with the previous study (Nordey et al., 2021), but surprisingly it was lower in both the varieties harvested from the poly-net houses. However, the iron supply from the pink poly-net house was comparable with the open field in the winter for both the amaranth crops but pink poly-net house was the highest iron supplier from water spinach in the winter. The poly-net houses were the sole supplier of iron through amaranth crops in the spring, although the niche was shared by open field with the pink poly-net house for the water spinach. It is important to note that only poly-net houses enabled the production of amaranth crops in the spring season, and the water spinach in the winter season.

While comparing pink poly-net house with the white polynet house, the supply of carotenoids and iron was comparatively better from the pink poly-net house in most of the seasons for all the three crops. A previous study from Japan also demonstrated that red amaranth grown under blue shade polyethylene 
TABLE 11 | Climatic conditions [temperature ( $\left.{ }^{\circ} \mathrm{C}\right)$, (Mean $\pm \mathrm{SD}$; Min-Max range), and relative humidity (\%RH), (Mean $\pm \mathrm{SD}$; Min-Max range)] during fall season (Sept 23-Oct 28, 2020), winter season (Dec 9 2020-Feb 8 2021), and spring season (March 24-May 5, 2021).

\begin{tabular}{|c|c|c|c|c|c|c|}
\hline \multirow[t]{2}{*}{ Treatment } & \multicolumn{2}{|c|}{ Fall Season } & \multicolumn{2}{|c|}{ Winter Season } & \multicolumn{2}{|c|}{ Spring Season } \\
\hline & $\mathbf{T}\left({ }^{\circ} \mathbf{C}\right)$ & $\%$ RH & $\mathbf{T}\left({ }^{\circ} \mathrm{C}\right)$ & $\% \mathbf{R H}$ & $\mathbf{T}\left({ }^{\circ} \mathrm{C}\right)$ & $\% \mathbf{R H}$ \\
\hline Open field & $25.7 \pm 1.5(20.8-33.9)$ & $81.5 \pm 4.1$ (58.8-97.2) & $16.1 \pm 2.9(11.0-23.5)$ & $83.8 \pm 6.5$ (57.6-98.1) & $23.2 \pm 2.0(17.9-30.5)$ & $80.7 \pm 6.2(56.2-97.4)$ \\
\hline Pink & $27.1 \pm 4.6(19.4-37.1)$ & $70.0 \pm 13.4(40.1-90.2)$ & $18.2 \pm 5.2(6.00-33.0)$ & $68.7 \pm 14.5(25.0-90.5)$ & $25.6 \pm 5.1(13.4-37.4)$ & $63.6 \pm 14.7(34.7-87.4)$ \\
\hline White & $27.2 \pm 4.5(19.5-37.4)$ & $72.3 \pm 13.1(43.4-92.4)$ & $18.4 \pm 5.2(6.6-33.2)$ & $72.0 \pm 14.6(27.5-94.3)$ & $25.8 \pm 5.0(13.9-37.4)$ & $68.6 \pm 14.0$ (39.9-90.3) \\
\hline
\end{tabular}

produced more biomass yield with health beneficiary bioactive compounds betacyanins, polyphenol and antioxidant activity during the low temperature regime in spring season (Khandaker et al., 2010). A recent study had assessed the effects of various ratios of combined red, blue, and amber light-emitting diodes on the expression of carotenoid biosynthetic genes and carotenoid accumulation in brassicas (Alrifai et al., 2021). It found that total and individual carotenoids were increased significantly under dose-dependent increasing amber-blue light and decreasing red in most brassica microgreens. According to this study, lipophilic 2,2-diphenyl-1-picrylhydrazyl and ferric reducing antioxidant power antioxidant activities were significantly increased under higher amber and blue light fractions, while oxygen radical absorbance capacity was generally decreased. Hence, the higher blue irradiance inside the pink net house than in the white polynet house and open field conditions could have involved in the regulatory mechanism of carotenoid biosynthesis in the current study, which requires further validation in future studies.

Based on the RDI values of iron and $\beta$-carotene, the number of people who could receive these nutrients from the crops harvested under different production conditions was estimated in the current study. During the off-season (winter for water spinach and spring for amaranths), pink poly-net house was estimated to supply more iron to people than the other production conditions. In all the seasons, the polynet houses provided more $\beta$-carotene than the open field produced crops. Hence, sufficient quantities of iron and $\beta$ carotene can be obtained from the leafy vegetables, particularly during the off-season using less cultivation area under protective structures. This is quite important in countries like Taiwan, where the overall share of agricultural land decreased during the last two decades (Chen et al., 2019). However, it should be noted that we made these theoretical estimates based on the RDI values, without considering the bioavailability. Hence, these results should be interpreted in terms of nutrient supply from different crop production conditions, but the actual contribution of these nutrients based on their bioavailability to improving health conditions should be investigated in further studies.

Thus, protected cultivation has demonstrated the supply of nutritious vegetables, especially during the off-season. Since the investment in the construction and maintenance of both the white and pink poly-net houses is similar, use of pink poly-net houses may be considered to produce more nutritious vegetables. Supply of vegetables during the off-season is quite important to bridge the gaps in the seasonal variations in vegetable consumption. In addition, off-season vegetable production can provide better income opportunities to the smallholder farmers. If properly constructed and maintained, protective structures will last longer and reduce the incidence of pests and diseases thus reducing the use of harmful chemical pesticides in vegetable production systems. Thus, protected cultivation is expected to build economic and environmental resilience to the smallholder vegetable producers, while supplying nutritious vegetables to the consumers, especially in the off-season. However, the impacts of different types of protected cultivation on the horticultural and nutritional yield are location- and crop-specific, which can be piloted in new locations before scaling out among smallholder farmers in Asia and Africa for better nutrition and incomes.

\section{DATA AVAILABILITY STATEMENT}

The raw data supporting the conclusions of this article will be made available by the authors, without undue reservation.

\section{AUTHOR CONTRIBUTIONS}

SR and PS-C: conceptualization and formal analysis. SR: funding acquisition and writing-original draft. SR, M-YL, WJW, H-IW, and PS-C: methodology and investigation. MYL, W-JW, H-IW, and PS-C: writing-review and editing. All authors have read and agreed to the published version of the manuscript.

\section{FUNDING}

Funding for this research was provided by the World Vegetable Center and by long-term strategic donors to the World Vegetable Center: Taiwan, the Foreign, the Commonwealth \& Development Office (FCDO) from the UK government, United States Agency for International Development (USAID), Australian Centre for International Agricultural Research (ACIAR), Germany, Thailand, Philippines, Korea, and Japan.

\section{ACKNOWLEDGMENTS}

The authors express their gratitude to the field staff of Safe and Sustainable Value Chains Flagship Program for their continuous support for the fieldwork. 


\section{REFERENCES}

Alrifai, O., Hao, X., Liu, R., Lu, Z., Marcone, M. F., and Tsao, R. (2021). LED-induced carotenoid synthesis and related gene expression in Brassica microgreens. J. Agric. Food Chem. 69, 4674-4685. doi: 10.1021/acs.jafc.1c00200

AOAC (1990). Official methods of Analyses. Method No. 975.03 metal in plants, AAS method, 15th ed. Arlington: Association of Official Analytical Chemists, Inc.

Arnao, M. B., Cano, A., and Acosta, M. (2001). The hydrophilic and lipophilic contribution to total antioxidant activity. Food Chem. 73, 239-244. doi: 10.1016/S0308-8146(00)00324-1

Asai, A., Yonekura, L., and Nagao, A. (2008). Low bioavailability of dietary epoxyxanthophylls in humans. Br. J. Nutr. 100, 273-277. doi: $10.1017 /$ S0007114507895468

Böhm, V., Lietz, G., Olmedilla-Alonso, B., Phelan, D., Reboul, E., Bánati, D., et al. (2020). From carotenoid intake to carotenoid blood and tissue concentrations - implications for dietary intake recommendations. Nutr. Rev. 79, 544-573. doi: 10.1093/nutrit/nuaa008Fnyo

Britton, G., Liaaen-Jensen, S., and Pfander, H. (2009). Carotenoids volume 5: nutrition and health. Birkhäuser: Basel, Switzerland. doi: 10.1007/978-3-7643-7501-0

Casal, J. J. (1994). Stem extension growth responses to blue light require Pfr in tomato seedlings but are not reduced by low phytochrome levels of the aurea mutant. Physiol. Plant. 91, 263-267. doi: 10.1111/j.1399-3054.1994.tb00428.x

Chandra-Hioe, M. V., Rahman, H. H., and Arcot, J. (2017). Lutein and $\beta$-Carotene in Selected Asian Leafy Vegetables. J. Food Chem. Nanotechnol. 3, 93-97. doi: $10.17756 /$ ifcn.2017-043

Chen, Y. Y., Huang, W., Wang, W. H., Juang, J. Y., Hong, J. S., Kato, T., et al. (2019). Reconstructing Taiwan's land cover changes between 1904 and 2015 from historical maps and satellite images. Sci. Rep. 9,3643. doi: 10.1038/s41598-019-40063-1

Ebert, A. W., Wu, T. H., and Wang, S. T. (2011). Vegetable amaranth (Amaranthus L.). International Cooperators' Guide. AVRDC Publication Number: 11-754. Shanhua, Tainan, Taiwan: AVRDC-The World Vegetable Center. Available online at: http://203.64.245.61/web_crops/indigenous/cooperators\%20guide_ amaranth_s_web.pdf

Fowler, D. (2011). Nutritional Value of Common Fruits \& Vegetables Grown in Cambodia. Cambodia: MCC Prey Veng. Available online at: https:// thehomeaway.files.wordpress.com/2011/09/nutritional-value- of-cambodiancrops.pdf

Genova, C., Weinberger, K., and Acedo, J.r., A.L. (2010). An Assessment of Market Opportunities for Leafy Vegetables in the Upland Areas of Cambodia, Laos, and Vietnam. Final Project Report, RETA 6376. AVRDC Publication No. 10-734. Taiwan: AVRDC - The World Vegetable Center. Available online at: https:// avrdc.org/wpfb-file/eb0128-pdf/

Grubben, G. J. H., and Van Sloten, D. H. (1981). Genetic resources of amaranths. Rome: IBPGR

Harmanto, Tantau, H., and Salokhe, V. M. (2006). Influence of insect screens with different mesh sizes on ventilation rate and microclimate of greenhouses in the humid tropics. Agricultural Engineering International: the CIGR Ejournal. Available online at: https://ecommons.cornell.edu/handle/1813/10512

Harmanto, T. H. J. (2006). Evaluation of net greenhouses for tomato production in the tropics. (Ph.D. dissertation) Hannover: University. Available online at: https://www.repo.uni-hannover.de/handle/123456789/6751

Ho, C. C. (2000). Spider-mite problems and control in Taiwan. Exp. Appl. Acarol. 24, 453-462. doi: 10.1023/A:1006443619632

Hsu, Y.-C., and Srinivasan, R. (2012). Desert horse purslane weed as an alternative host for amaranth leaf webber, Hymenia recurvalis in Taiwan. Formos. Entomol. 32, 297-302. Available online at: http://entsocjournal.yabee.com.tw/ AlldataPos/JournalPos/Vol32/No3/TESFE.2012018.PDF

Hwang, S.-G., Chao, H.-C., and Lin, H.-L. (2018). Differential responses of pak choi and edible amaranth to an elevated temperature. Hort. Sci. 53, 195-199. doi: 10.21273/HORTSCI12667-17

Ilić, Z. S., Milenković, L., Šunić, L., and Manojlović, M. (2018). Color shade nets improve vegetables quality at harvest and maintain quality during storage. Contemp. Agric. 67, 9-19. doi: 10.2478/contagri-20180002
Institute of Medicine (2001). Dietary Reference Intakes for Vitamin A, Vitamin K, Arsenic, Boron, Chromium, Copper, Iodine, Iron, Manganese, Molybdenum, Nickel, Silicon, Vanadium, and Zinc. Washington, DC: Institute of Medicine.

Joosten, F. J., Dijkxhoorn, Y., Sertse, Y., and Ruben, R. (2015). How does the fruit and vegetable sector contribute to food and nutrition security? LEI Nota 2015-2076, June 2015. Wageningen: LEI Wageningen UR. pp. 57. Available online at: https://edepot.wur.nl/348737

Khanam, U. K. S., and Oba, S. (2013). Bioactive substances in leaves of two amaranth species, Amaranthus lividus and A. hypochondriacus. Canadian J. Plant Sci. 93, 47-58. doi: 10.4141/cjps2012-117

Khandaker, L., Masum Akond, A. S. M. G., Ali, M. B., and Oba, S. (2010). Biomass yield and accumulations of bioactive compounds in red amaranth (Amaranthus tricolor L.) grown under different colored shade polyethylene in spring season. Sci. Hortic. 123, 289-294. doi: 10.1016/j.scienta.2009.09.012

Khoo, H.-E., Nagendra, P. K., Kong, K.-W., Jiang, Y., and Ismail, A. (2011). Carotenoids and their isomers: color pigments in fruits and vegetables. Molecules. 16, 1710-1738. doi: 10.3390/molecules 16021710

Lee, W.-S., and Yang, S.-R. (1999). Using a plug system to produce hygienic vegetables. Food and Fertilizer Technology Center for the Asian and Pacific Region. Taipei. Available online at: https://www.fftc.org.tw/htmlarea_file/ library/20110809105010/eb477.pdf

Liou, T. (1981). Studies on seed production techniques of water convolvulus (Ipomoea Aquatica Forsk.)-II. Effect of planting dates on the seed production potentiality of different cultivars of water convolvulus grown under paddy and upland fields. J. Agric. Res. China. 30, 385-394.

Long, S. P. (1999). "Environmental responses," in the C4 Plant Biology, eds. R.F. Sage and R.K. Monson (San Diego, CA: Academic Press) 215-249. doi: 10.1016/B978-012614440-6/50008-2

Majumdar, A., and Powell, M. (2011). Net house vegetable production: pest management success and challenges. J. NACAA. 4. Available online at: https:// www.nacaa.com/journal/index.php?jid=87

Makobo, N. D., Shoko, M. D., and Mtaita, T. A. (2010). Nutrient content of amaranth (Amaranthus cruentus L.) under different processing and preservation methods. World J. Agric. Sci. 6, 639-643.

Maoka, T., and Etoh, H. (2010). "Some biological functions of carotenoids in Japanese food", in Functional Foods of the East John Shi, Chi-Tang Ho, eds Fereidoon Shahidi. (Boca Raton: CRC Press), 85-97.

Muniappan, R., Shepard, B. M., Carner, G. R., and Ooi, P. A. C. (2012). Arthropod pests of horticultural crops in tropical Asia. Wallingford, Oxfordshire: CABI. doi: 10.1079/9781845939519.0000

National Research Council. (1984). Amaranth: Modern prospects for an ancient crop. Washington, DC: The National Academies Press. 74 p.

Nihoul, P., Van Impe, G., and Hance, T. (1991). Characterizing indices of damage to tomato by the two-spotted spider mite, Tetranychus urticae Koch (Acari: Tetranychidae) to achieve biological control. J. Hortic. Sci. 66, 643-648. doi: 10.1080/00221589.1991.11516195

Nordey, T., Basset-Mens, C., De Bon, H., Martin, T., Déletré, E., Simon, S., et al. (2017). Protected cultivation of vegetable crops in sub-Saharan Africa: limits and prospects for smallholders. A review. Agron. Sustain. Dev. 37, 53. doi: 10.1007/s13593-017-0460-8

Nyonje, W. A., Schafleitner, R., Abukutsa-Onyango, M., Yang, R.-Y., Makokha, A., and Owino, W. (2021). Precision phenotyping and association between morphological traits and nutritional content in Vegetable Amaranth (Amaranthus spp.). J. Agric. Food Res. 5:100165. doi: 10.1016/j.jafr.2021.100165

Palada, M. C., and Wu, D. L. (2009). Grafting sweet peppers for production in the hot-wet season. International Cooperator's Guide, AVRDC Publication Number:09-722-e. Available online at: http://203.64.245.61/fulltext_pdf/ FLYER/f0002.pdf

Pan, W.-H., Yeh, N.-H., Yang, R.-Y., Lin, W.-H., Wu, W.-C., Yeh, W.-T., et al. (2018). Vegetable, fruit, and phytonutrient consumption patterns in Taiwan. J. Food Drug Anal. 26: 145-153. doi: 10.1016/j.jfda.2016.12.015

Pinker, I., Bubner, U., and Böhme, M. (2007). Selection of water spinach (Ipomoea aquatica Forssk.) genotypes for protected cultivation in temperate regions. Acta. Hortic. 752, 441-446. doi: 10.17660/ActaHortic.2007. 752.80

Polston, J. E., and Lapidot, M. (2007). "Management of tomato yellow leaf curl virus: US and Israel perspectives", in Tomato Yellow Leaf Curl Virus Disease: 
Management, Molecular Biology, Breeding for Resistance, ed. H. Czosnek (The Netherlands; Springer), 251-262. doi: 10.1007/978-1-4020-4769-5_15

Rodriguez-Amaya, D. B., and Kimura, M. (2004). Harvest plus handbook for carotenoids analysis. HarvestPlus Technical Monograph 2. Washington, DC and Cali: International Food Policy Research Institute (IFPRI) and International Center for Tropical Agriculture (CIAT). Available online at: http://ebrary.ifpri. org/utils/getfile/collection/p15738coll2/id/125148/filename/125149.pdf

Sarker, U., and Oba, S. (2020). Leaf pigmentation, its profiles and radical scavenging activity in selected Amaranthus tricolor leafy vegetables. Sci. Rep. 10, 18617. doi: 10.1038/s41598-020-66376-0

Schreinemachers, P., Chen, H. P., Nguyen, T. T. L., Buntong, B., Bouapaoe, L., Gautam, S., et al. (2017). Too much to handle? Pesticide dependence of smallholder vegetable farmers in Southeast Asia. Sci. Total Environ. 593-594, 470-477. doi: 10.1016/j.scitotenv.2017.03.181

Shahak, Y., Ratner, K., Zur, N., Offir,Y., Matan, E., Yehezkel, H., et al. (2008). Photoselective netting: An emerging approach in protected agriculture. Acta Hortic. 807, 79-84. doi: 10.17660/ActaHortic.2009.807.7

Smith, J. D., Dinssa, F. F., Anderson, R. S., Su, F.-C., and Srinivasan, R. (2018). Identification of major insect pests of Amaranthus spp. and germplasm screening for insect resistance in Tanzania. Int. J. Trop. Insect Sci. 38, 261-273. doi: $10.1017 /$ S1742758418000115

Talekar, N. S., Su, F. C., and Lin, M. Y. (2003). How to produce safer leafy vegetables in net houses and net tunnels. Shanhua, Tainan, Taiwan: Asian Vegetable Research and Development Center. 18pp.

Towns, A. M., and Shackleton, C. (2018). Traditional, indigenous, or leafy? A definition, typology, and way forward for African vegetables. Econ Bot. 72, 461-477. doi: 10.1007/s12231-019-09448-1
Wang, S. T., and Ebert, A. W. (2012). Breeding of leafy amaranth for adaptation to climate change. In: Proceedings from SEAVEG 2012: Regional Symposium on High Value Vegetables in Southeast Asia: Production, Supply and Demand, 24-26 January 2012. Chiang Mai, Thailand. pp. 36-43.

Westphal, E. (1994). "Ipomoea aquatica" in Plant resources of South-East Asia, No 8 Vegetables, Bongor, Indonesia, eds. S. Siemonsma and K. Piluek (Wageningen, Netherlands: Pudoc), 181-184.

Conflict of Interest: The authors declare that the research was conducted in the absence of any commercial or financial relationships that could be construed as a potential conflict of interest.

Publisher's Note: All claims expressed in this article are solely those of the authors and do not necessarily represent those of their affiliated organizations, or those of the publisher, the editors and the reviewers. Any product that may be evaluated in this article, or claim that may be made by its manufacturer, is not guaranteed or endorsed by the publisher.

Copyright $\odot 2021$ Ramasamy, Lin, Wu, Wang and Sotelo-Cardona. This is an open-access article distributed under the terms of the Creative Commons Attribution License (CC BY). The use, distribution or reproduction in other forums is permitted, provided the original author(s) and the copyright owner(s) are credited and that the original publication in this journal is cited, in accordance with accepted academic practice. No use, distribution or reproduction is permitted which does not comply with these terms. 